\title{
ANTUNES, António Lobo. Boa tarde às coisas aqui em baixo. Rio de Janeiro: Objetiva, 2003.
}

Denis Leandro Francisco Universidade Federal de Minas Gerais

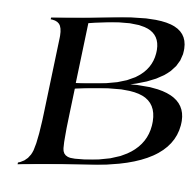

oa tarde às coisas aqui em baixo, de António Lobo Antunes, foi selecionado para concorrer ao prêmio Portugal Telecom de Literatura em Língua Portuguesa 2007, passou à segunda fase do prestigiado concurso e foi classificado como finalista, mas Jerusalém, do também português Gonçalo Tavares, acabou recebendo a premiação. Esse curioso "romance em três livros com prólogo e epílogo", conforme se pode ler nas suas páginas de abertura, evoca em seu título uma frase singular e "intraduzível" - singularidade e intraduzibilidade que irão se reafirmar ao longo dessa vasta narrativa que cruza espacialidades portuguesas e angolanas numa torrente de rememorações atormentadas.

Não é sem razão que os diversos narradores que se alternam e se confundem em meio à convulsão narrativa desses excertos de histórias reclamam ajuda para narrar suas vidas irrecorrivelmente estraçalhadas: "Tão difícil explicar-me, de que maneira explicar-me, como se diz isto, quem me ajuda a contar, a ser a pá que desperta o sono, dilacera a garganta da terra e traz à luz os ossos sob as folhas secas?". ${ }^{1}$ Também o leitor, ao percorrer páginas e páginas da mais extenuante dispersão do acontecimento romanesco, vê-se impelido a abandonar sua tradicional atitude de investigador dos fatos narrados e aceitar que a esse quebracabeças ficcional faltam incontáveis

\footnotetext{
${ }^{1}$ ANTUNES, 2003, p. 45.
} 
peças - ou que para se jogar o jogo da leitura desse romance antuniano há que se aprender a jogar com peças que, aparentemente, não se encaixam.

Uma mulher de nome Marina mostra a um sujeito anônimo o que julga ser a casa onde vivera, há vinte anos, na Muxima - vila e município da província do Bengo, em Angola. Lampejos de tropas do governo, cubanos, mercenários de toda ordem - franceses e belgas, negros e brancos -, praias transformadas num baldio de misérias, repletas de indigentes, de cegos e crianças de muletas - "visto que todas as crianças usam muletas em Angola" - constroem um panorama de uma Angola pós-descolonização e pós-esperança, nessa cena continuamente entrecortada pela voz da tal mulher a afirmar reiteradamente: "- Esta era a casa". Essa casa, invadida pela erva, afogada em destroços, a arder em chamas desde a fundação até o teto, terá, logo em seguida, o que restou de suas paredes derrubado por um trator conduzido por essa mesma mulher que, ao que parece, deseja, a todo custo, soterrar o passado ou o que quer que tenha sobejado dele. Tradicionalmente, o prólogo consiste em uma cena introdutória na qual se fornecem dados prévios elucidativos do enredo da peça ao menos assim se dava na tragédia, no antigo teatro grego. Em $\mathrm{Boa}$ tarde às coisas aqui em baixo, o prólogo, acima brevemente descrito, algo se exime de elucidar o que quer que seja, cabendo ao leitor do texto antuniano, muito mais do que se exigia do espectador da tragédia grega, empenhar-se na busca de relações e diálogos entre o que ali revoltamente se apresenta e o que se desenvolverá nos capítulos subseqüentes.

O primeiro livro alterna as histórias de Seabra, agente enviado a Angola pelo "Serviço" - um órgão militar português não-oficial -, e dessa mesma Marina, africana mestiça, filha de pai negro e mãe branca, sobrinha de um procurado contrabandista de diamantes. A tarefa do agente Seabra é localizar os diamantes que estão em poder do tal contrabandista e, claro, eliminá-lo. Mas ocorre que, um a um, esses agentes enviados à excolônia portuguesa, estranhamente, não retornam de suas missões, desaparecendo sem deixar vestígios, como se devorados pela terra de África, e tendo de ser substituídos por outro, e outro e mais outro, como touros continuamente

\footnotetext{
${ }^{2}$ ANTUNES, 2003, p. 19.
} 
abatidos em um espetáculo de arena.

O segundo livro é narrado pela voz de Miguéis, novo agente enviado para limpar os rastos deixados pelo seu antecessor - incluindo este próprio - e recuperar as pedras. Em meio a confusas e variadas referências a ordens e relatórios, mapas e coordenadas, fronteiras e rios, perpassam considerações subjetivas e reminiscências de coisas irrecuperáveis - que vão desde pais que se tenta, sem sucesso, agradar e copiar, passando por vidas conjugais desfeitas e filhos que não respondem à demanda de afeto de seus pais e vice-versa, até escarnecedores patos de plástico da infância -, coisas irrecuperáveis e que, contudo, não cessam de perseguir esses sujeitos, persistentes "como certas memórias, certos remorsos, certos ecos compridos, o apito dos navios por exemplo mesmo depois dos navios, durante anos, a gente a cuidar que os esqueceu e o apito de volta". ${ }^{3} \mathrm{~A}$ vOz insegura de Miguéis cede lugar ou é inadvertidamente atravessada - às não menos débeis vozes de sua esposa e de sua filha personagem que também oferece uma versão de sua vida junto aos pais, recorda a partida do namorado e a visita de despedida que lhe faz o pai, a dor e o tormento da doença que a transforma em uma espécie de "espantalho" e a faz desejar uma única coisa: "que me deixem em paz sozinha comigo ou antes sozinha com isto que não sou eu e em que me tornei". ${ }^{4}$ Narradores que não se decidem sobre se áceres ou carvalhos, se este ou aquele nome, se Marimbanguengo ou se o Congo e para os quais qualquer tentativa de evadir essa vida de degradação e de remorsos afigurase impossível, "dado ser tarde compreende, não apenas tarde para mim, tarde para si também". 5 Tarde, sem exceção, para todos.

O terceiro livro acompanha a peregrinação de um grupo de cinco homens, todos ex-agentes dissidentes do Serviço português, pela mata de Angola, na tentativa desesperada de alcançar a fronteira com o Congo, carregando os diamantes que serão contrabandeados. Perseguidos por militares e americanos que tentam resgatar as jóias, esses pobres touros desgarrados rememoram suas vivências cotidianas e nada exemplares, em meio à tensão e

\footnotetext{
${ }^{3}$ ANTUNES, 2003, p. 278.

${ }^{4}$ ANTUNES, 2003, p. 333.

${ }^{5}$ ANTUNES, 2003, p. 343.
} 
iminência de uma morte inevitável. Intercalando dialogicamente, cada um dos dez capítulos que compõem essa parte, a voz de cada um dos cinco fugitivos à voz de Morais, o agente que os persegue, esse último livro constitui-se em uma explosão de imagens do passado embaralhadas às cenas atuais que convergem para a emboscada da qual esses homens se aproximam. Gonçalves, com seus pais, mães e cães a saltitarem raivosamente da memória; Mateus, que se perde nas confusas linhas do mapa que carrega e que mal lê e nas não menos confusas recordações de filhas, esposas e padres pedófilos; Mendonça, que sonha abrir um café na Argentina enquanto é dilacerado pela origem mestiça da irmã - a quem amava e odiava amar; Sampaio, traidor contratado pelos americanos para conduzir o grupo ao local da armadilha, com sua onipresente imagem de uma irmã levada de casa ainda criança pelo pai e que não lhe concede um só instante de paz; Tavares, que, ferido no joelho, põe-se a recordar as últimas e ambivalentes férias passadas com a família em Portugal; e, finalmente, o próprio agente Morais, perseguidor que é ao mesmo tempo perseguido, também ele, por uma esposa, uma mãe ausente sob a chuva, um filho e comboios do passado. Nessa narração absurdamente insegura e provisória, que se erige sobre a incerteza, sobre a desordem irrevogável da desmemória - "não estou bem seguro e já não estou seguro de nada" - , nada de permanente irá se afirmar ou, talvez, um único elemento se projete no texto, após o desaparecimento, de uma forma ou de outra, de todas as personagens, todas as reminiscências e de todo o narrado: a terra vermelha (ou amarela?) de Angola, a tragar indistintamente tudo e todos para o seu interior, "porque tudo pertence à terra em Angola, as nuvens, por exemplo, que bem as noto a descer no capim, as pessoas e as casas que regressam ao chão depois de se agitarem um momento numa pergunta a que nada responde". ${ }^{7}$ Finalmente, o epílogo consiste em uma inusitada redação infantil, redigida por uma garotinha a mando do professor de Português, sobre as "férias grandes" que passou com a família a bordo de um iate em Luanda. A paisagem paradisíaca e de calmaria apresentada nessa cena final contrasta com as imagens de caos, desespero e miséria da

\footnotetext{
${ }^{6}$ ANTUNES, 2003, p. 216.

7 ANTUNES, 2003, p. 100.
} 
guerra pelas riquezas que brotam do solo angolano. A ingenuidade que emana da narrativa da criança, assim como a simplicidade da forma de sua expressão escrita, por sua vez, opõem-se à ferocidade da narrativa como um todo, bem como serve de afronta à ganância dos adultos que mandam e desmandam, para garantir interesses próprios, nas terras e nas vidas alheias. Reunindo, em uma mesma massa "amorfa", raças, classes sociais, temporalidades e espacialidades heterogêneas e disjuntivas, a narrativa "líquida" de Lobo Antunes expõe a violenta degradação imposta a sujeitos em sua luta por uma improvável emancipação. A incômoda irresolução do narrado com seu sentido errante que circula incessantemente sem se fixar em parte alguma da escrita - faz ecoar a afirmação, enunciada por um dos narradores, de que a existência é uma pergunta à qual nada responde. Frente às coisas inacreditáveis desse mundo de "aqui em baixo", como intui prematuramente a criança que escreve, apenas o assombro e a estupefação: "e a próxima vez que o filho do caro almirante desapertar as calças juro que lhe toco para ter a certeza que aquilo que me mostrou é verdade".

${ }^{8}$ ANTUNES, 2003, p. 565. 